\title{
DEVELOPMENT OF ODS HEAT EXCHANGER TUBING
}

Quarterly Technical Progress Report

For

January 1, 2002 through April 1, 2002

Mark A. Harper, Ph.D.

Principal Investigator

April, 2002

DOE Award Number DE-FC26-00NT40970

Huntington Alloys

3200 Riverside Drive

Huntington, WV 25705 
DISCLAIMER

THIS REPORT WAS PREPARED AS AN ACCOUNT OF WORK SPONSORED BY AN AGENCY OF THE UNITED STATES GOVERNMENT. NEITHER THE UNITED STATES GOVERNMENT NO ANY AGENCY THEREOF, NOR ANY OF THEIR EMPLOYEES, MAKES ANY WARRANTY, EXPRESS OR IMPLIED, OR ASSUMES, ANY LEGAL LIABILITY OR RESPONSIBILITY FOR ACCURACY, COMPLETENESS, OR USEFULNESS OF ANY INFORMATION, APPARATUS, PRODUCT, OR PROCESS DISCLOSED, OR REPRESENTS THAT ITS USE WOULD NOT INFRINGE PRIVATELY OWNED RIGHTS. REFERENCE HEREIN TO ANY SPECIFIC COMMERCIAL PRODUCT, PROCESS, OR SERVICE BY TRADE NAME, TRADEMARK, MANUFACTURER, OR OTHERWISE DOES NOT NECESSARILY CONSTITUTE OR IMPLY ITS ENDORSEMENT, RECOMMENDATION, OR FAVORING BY THE UNITED STATES GOVERNMENT OR ANY AGENCY THEREOF. THE VIEWS AND OPINIONS OF AUTHORS EXPRESSED HEREIN DO NOT NECESSARILY STATE OR REFLECT THOSE OF THE UNITED STATES GOVERNMENT OR ANY AGNECY THEREOF.

DISCLAIMER OF WARRANTIES AND LIMITATION OF LIABILITIES THIS REPORT WAS PREPARED BY THE ORGANIZATION(S) NAMED BELOW AS AN ACCOUNT OF WORK SPONSORED OR COSPONSORED BY THE U.S. DEPARTMENT OF ENERGY AND HUNTINGTON ALLOYS. NEITHER THE U.S. DEPARTMENT OF ENERGY, HUNTINGTON ALLOYS, THE ORGANIZATION(S) NAMED BELOW, NOR ANY PERSON ACTING ON BEHALF OF ANY OF THEM: (A) MAKES ANY WARRANTY OR REPRESENTATION WHATSOEVER, EXPRESS OR IMPLIED, (I) WITH RESPECT TO THE USE OF ANY INFORMATION, APPARATUS, METHOD, PROCESS, OR SIMILAR ITEM DISCLOSED IN THIS REPORT, INCLUDIGN MERCHANTABILITY AND FITNESS FOR A PARTICULAR PURPOSE, OR (II) THAT SUCH USE DOES NOT INFRINGE ON OR INTERFERE WITH PRIVATELY OWNED RIGHTS, INCLUDING ANY PARTY'S INTELLECTUAL PROPERTY OR (III) THAT THIS REPORT IS SUITABLE TO ANY PARTICULAR USERS CIRCUMSTANCE; OR (B) ASSUMES ANY RESPONSIBILITY FOR ANY DAMAGES OR OTHER LIABILITY WHATSOEVER (INCLUDING ANY CONSEQUENTIAL DAMAGES, EVEN IF DOE OR ANY DOE REPRESENTATIVE HAS BEEN ADVISED OF THE POSSIBILITY OF SUCH DAMAGES) RESULTING FROM YOUR SELECTION OR USE OF THIS REPORT OR ANY INFORMATION, APPARATUS, METHOD, PROCESS, OR SIMILAR ITEM DISCLOSED IN THIS REPORT.

[ORGANIZATION(S) THAT PREPARED THIS REPORT:]

Huntington Alloys $\quad$ Michigan Technology University

Oak Ridge National Laboratory $\quad$ Foster Wheeler Development Corporation

Edison Welding Institute University of California at San Diego 


\begin{abstract}
Work continued on three major tasks of this project - increasing the circumferential strength of MA956 tubing, joining of the MA956 alloy, and determination of the high temperature corrosion limits of the MA956 alloy. With respect to increasing the circumferential strength of a MA956 tube, all of the cold working operations $(0,10,20$, $30,40 \%)$ and annealing treatments $\left(1000,1150,1300^{\circ} \mathrm{C}\right)$ have been completed. The sample microstructures produced by this processing continue to be analyzed with TEM results providing valuable information on the strengthening mechanism of this alloy. Creep testing to determine the "stress threshold" curves for this alloy continues. Regarding joining of the MA956 alloy, additional welds were produced with the friction welding and transient liquid phase bonding techniques. And finally, laboratory high temperature corrosion testing of the material continues in both fluid-side and fire-side simulated environments.
\end{abstract}




\section{TABLE OF CONTENTS}

$\underline{\text { Section }}$

$\underline{\text { Page \# }}$

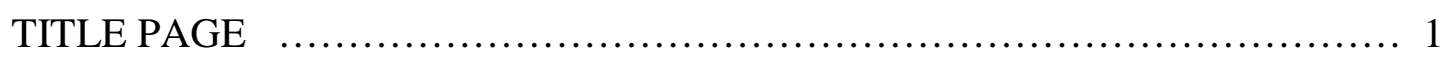

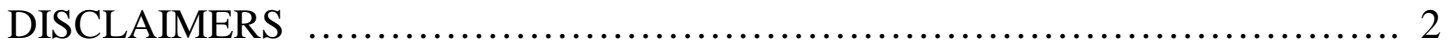

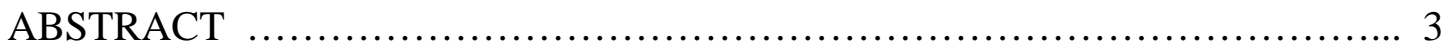

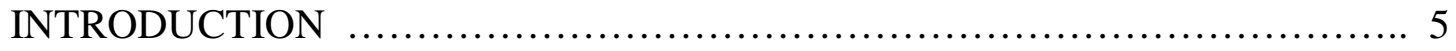

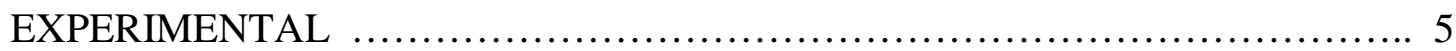

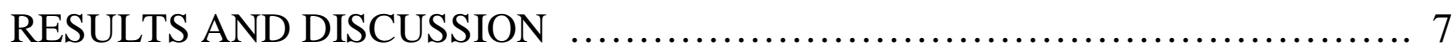

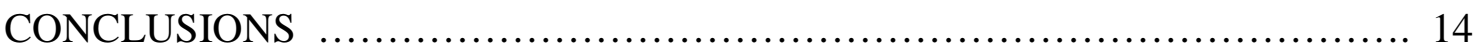




\section{INTRODUCTION}

This research is seeking to develop a MA956 heat exchanger tube that will lead to the design and fabrication of a MA956 full-scale tube heat exchanger composed of the referenced alloy. The alloy MA956 is an oxide dispersion strengthened (ODS) material that possesses superior creep strength and corrosion resistance at very high temperatures (e.g. $\mathrm{T}>2000^{\circ} \mathrm{F}$ ) compared to traditional wrought or cast alloys. However, the creep properties are unidirectional (typically stronger in the longitudinal direction compared to the transverse direction), fabrication of components made from this alloy is relatively difficult, and the corrosion limits of the alloy MA956 in coal-fired environments are not known. Thus, the technical tasks being executed in this Vision 21 project are:

Task 1: Project Management

Task 2: Improvement of Circumferential Creep Strength of MA956 Tubes

Task 3: Joining

Task 4: Bending of MA956 Tubes

Task 5: High Temperature Corrosion Limits of MA956

Task 6: Generation of Data for Designers

Task 7: Implication of ODS Properties on Heat Exchanger Design

Task 8: Reporting

The members of the team conducting this research are: Huntington Alloys (HA), Foster Wheeler Development Corporation (FWDC), Oak Ridge National Laboratory (ORNL), University of California, San Diego (UCSD), Michigan Technological University (MTU), and the Edison Welding Institute (EWI).

\section{EXPERIMENTAL}

Experimental work associated with the tasks identified in the previous section is discussed below.

\section{Task 2: Improvement of Circumferential Creep Strength of MA956 Tubes}

The following matrix of tests shown in Table 1 is currently being performed at HA. The execution of this matrix will result in 540 different combinations of extrusion + thermomechanical + annealing parameters. Table 2 shows the work that has been completed thus far.

Table 1

Matrix of Extrusion + Cold Work + Recrystallization Parameters

\begin{tabular}{|c|c|c|c|c|}
\hline $\begin{array}{c}\text { Extrusion } \\
\text { Temp }\left({ }^{\circ} \mathbf{C}\right)\end{array}$ & $\begin{array}{c}\text { Extrusion } \\
\text { Ratio }\end{array}$ & $\begin{array}{c}\text { Amount of } \\
\text { Cold Work }(\boldsymbol{\%})\end{array}$ & $\begin{array}{c}\text { Recrystallization } \\
\text { Temp }\left({ }^{\circ} \mathbf{C}\right)\end{array}$ & $\begin{array}{c}\text { Recrystallization } \\
\text { Time (h) }\end{array}$ \\
\hline 1000 & $10: 1$ & 0 & 1000 & 0.5 \\
1075 & $16: 1$ & 5 & 1150 & 1 \\
1150 & $20: 1$ & 10 & 1300 & 6 \\
1200 & & 15 & & \\
& & 25 & & \\
\hline
\end{tabular}


Table 2

Work Completed on Extruded + Cold Work + Recrystallized Samples

\begin{tabular}{|c|c|c|c|}
\hline Operation & Number Required & Number Complete & \% Complete \\
\hline Extrusion & 180 & 180 & 100 \\
\hline Decanning & 540 & 540 & 100 \\
\hline Cold Work & 540 & 540 & 100 \\
\hline Annealing & 540 & 500 & 92 \\
\hline Samples Prepared & 540 & 291 & 54 \\
\hline $\begin{array}{c}\text { Microstructure } \\
\text { Analysis }\end{array}$ & 540 & 147 & 27 \\
\hline
\end{tabular}

Transverse creep samples were machined from the tube that had been cut in half and testing initiated.

\section{Task 3: Joining}

Friction Welding: Previous testing had demonstrated the ability to friction weld the MA956 alloy. In an effort to determine how robust the friction welding process is with respect to joining MA956 tubing, a Design of Experiments has begun to evaluate the effect of different process parameters on elevated temperature joint properties.

Transient Liquid Phase Bonding: TLP bonding trials were conducted on 2.5" OD tubing this last quarter.

Explosive Welding: No further explosive welds were completed during this quarter.

Magnetic Impulse Welding: The new $90 \mathrm{kj}$ magnetic impulse welder has been installed at EWI and "shakedown" testing of the system continues. Also, a lap joint configuration has been designed and produced on the MA956 tubing for initial weld trials.

\section{Task 4: Bending of MA956 Tubes}

No work was performed on this task this quarter.

\section{Task 5: High Temperature Corrosion Limits of MA956}

The lifetime exposure testing at 1100,1200 , and $1250^{\circ} \mathrm{C}$ continues. Also, laboratory fireside corrosion testing continues.

Task 6: Generation of Data for Designers

No experimental work has been accomplished on this task during this reporting period.

\section{Task 7: Implication of ODS Properties on Heat Exchanger Design}

No experimental work has been accomplished on this task during this reporting period. 


\section{RESULTS AND DISCUSSION}

\section{Task 2: Improvement of Circumferential Creep Strength of MA956 Tubes}

Microstructural analysis has revealed transverse grain growth is frequently pinned by coarse particles that are aligned along the extrusion axis (see Figure 1). Also, microstructures that have experienced creep at ORNL have been examined with TEM. Figure 2 is a TEM micrograph of the microstructure of a sample exposed to a high stress for a short time $(10 \mathrm{ksi} /<1 / 2$ hour $)$ at $900^{\circ} \mathrm{C}$. As seen in this figure, the microstructure has the ability to develop and sustain a high density of dislocation network with the dislocations suitably pinned by dispersoids as shown in Figure 3. And finally, Figure 4 shows grain boundary migration with segments pinned by large dispersoids, thus giving initial evidence that the boundaries may be mobile at $900^{\circ} \mathrm{C}$ under high stress $(10 \mathrm{ksi})$.

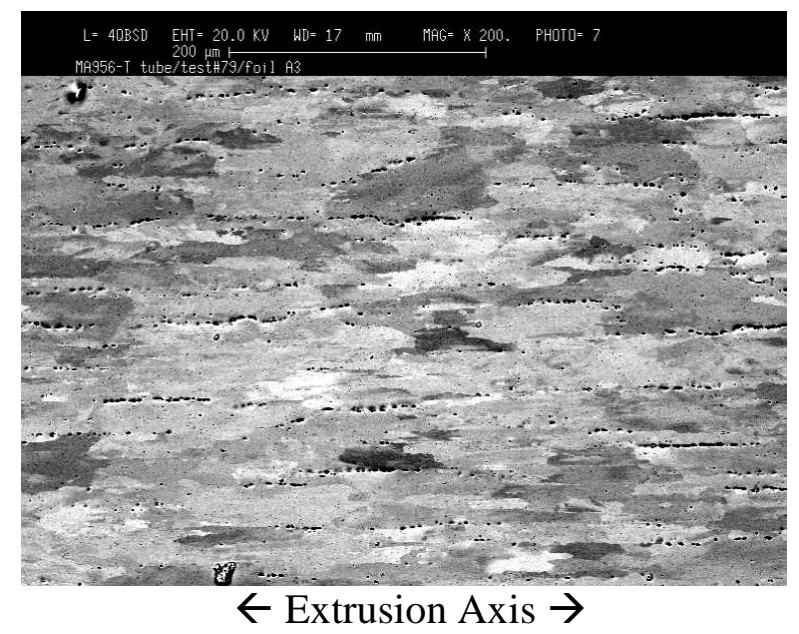

Figure 1. Backscattered SEM micrograph of specimen extracted from flattened MA956 tube showing trails of course particles pinning grain boundaries.

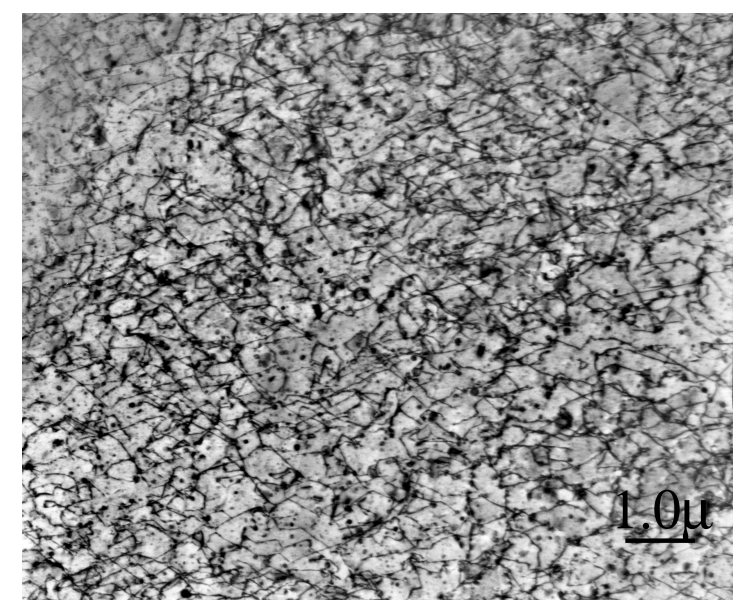

Figure 2. TEM micrograph of transverse oriented creep sample subjected to high stress for a short time $(10 \mathrm{ksi} /<1 / 2$ hour $)$ at $900^{\circ} \mathrm{C}$. 


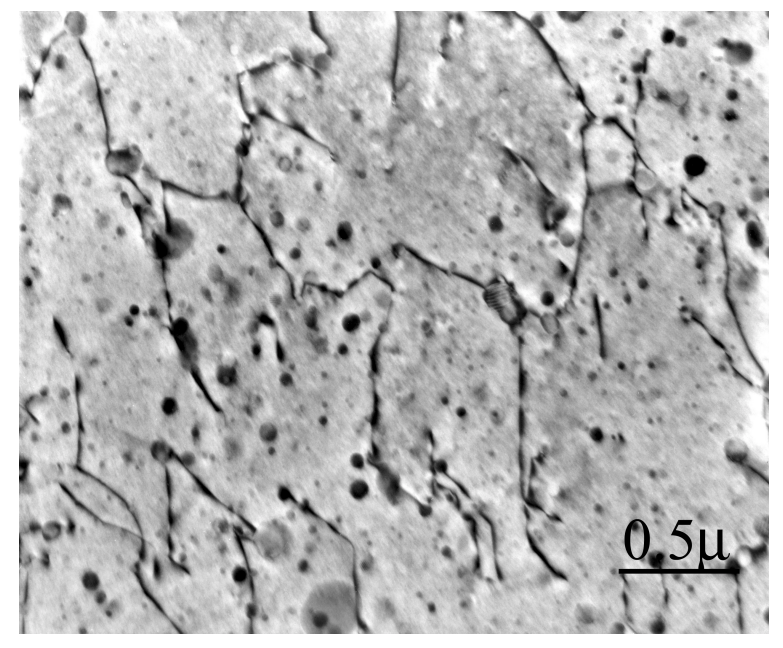

Figure 3. TEM micrograph of transverse oriented creep sample subjected to high stress for a short time $(10 \mathrm{ksi} /<1 / 2$ hour $)$ at $900^{\circ} \mathrm{C}$ showing stable dislocation pinning by dispersoid particles.

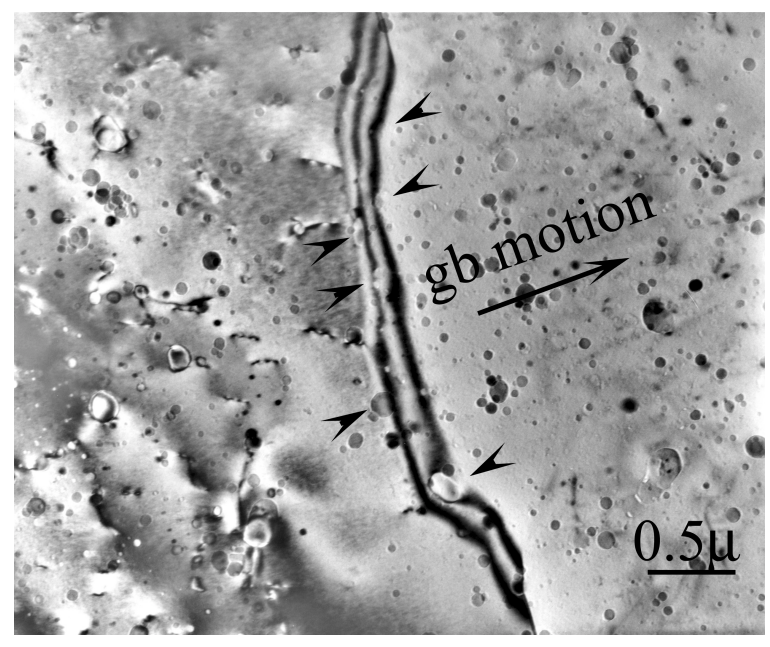

Figure 4. TEM micrograph of transverse oriented creep sample subjected to high stress for a short time (10 ksi / < 1/2 hour) at $900^{\circ} \mathrm{C}$ showing grain boundary migration under the applied stress and the drag exerted by coarse particles (as marked) in the microstructure.

The current compilation of data for the creep threshold curves for specimens cut from two tubes of different diameter, and from a flattened tube, are shown in Figure 5. The transverse direction creep threshold stresses determined for specimens cut from a flattened $6 \mathrm{~cm}$ OD x $5 \mathrm{~mm}$ wall tube are significantly lower than those determined for the longitudinal direction for specimens cut from a non-flattened tube. While this was expected - it is the basis for this project - the comparison is not straightforward since the grain sizes of the two heats of alloy are significantly different. 


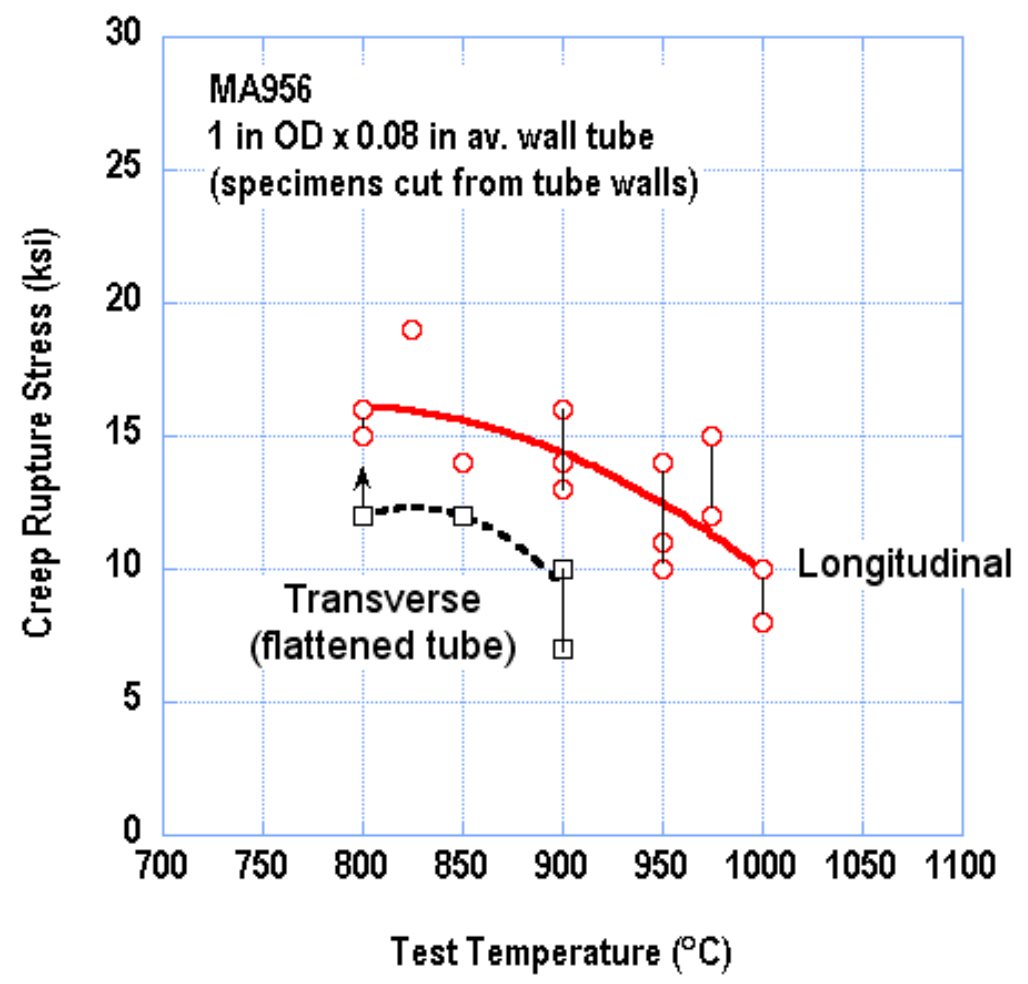

Figure 5. Longitudinal and transverse creep threshold curves for specimens cut from MA956 tubes. Note that the transverse samples were taken from a flattened $6 \mathrm{~cm}$ OD x 5 $\mathrm{mm}$ wall tube.

\section{Task 3: Joining}

Friction welding: Previous reported activity demonstrated the ability to friction weld MA956 to MA956 with room temperature tensile strengths approaching that of the base metal. However, it was not clear how robust of processing window was required to make an acceptable joint and meet the applicable/functional requirements of the Vision 21 Program. Thus in an effort to better understanding the effects of the friction welding parameters on the MA956 tubing, a small Design Of Experiments (DOE) task was initiated to evaluate the effect of different process parameters on the elevated temperature performance of Inertia Friction Welded (IFW) joints in MA956 alloy. As a screening test of the process parameters, elevated temperature tensile tests at $1200^{\circ} \mathrm{F}$ and charpy impact testing of the joints will be conducted.

Variables under investigation in the DOE study include initial surface velocity, or speed, and the welding force in the IFW process. Currently all welds have been made for the MA956/MA956 non-recrystallized couple and samples have been machined for testing. Based on these results other DOE studies for optimization may be conducted for the other material couples under investigation in the program. The process parameters of the current testing as well as weld features are indicated in Table 1 and photomicrographs of each sample are shown in Figures 6 through 9 below. 
Table 1

Process Parameters for the Design of Experiments Being Conducted for Inertia Friction Welding of the MA956 alloy

\begin{tabular}{|c|c|c|c|c|c|c|}
\hline Sample & $\begin{array}{c}\text { Speed } \\
(\mathrm{RPM})\end{array}$ & $\begin{array}{c}\text { Force } \\
(\mathrm{PSI})\end{array}$ & $\begin{array}{c}\text { Mechanically } \\
\text { Mixed Zone } \\
\text { width }(\mathrm{mm})\end{array}$ & $\begin{array}{c}\text { Plasticized } \\
\text { Zone width } \\
(\mathrm{mm})\end{array}$ & $\begin{array}{c}\text { HAZ Width } \\
\text { thermal }(\mathrm{mm})\end{array}$ & $\begin{array}{c}\text { Burnoff } \\
(\mathrm{mm})\end{array}$ \\
\hline 5 & 425 & 25000 & 0.0425 & 0.50 & 1.10 & 1.77 \\
\hline 6 & 625 & 25000 & 0.0825 & 0.54 & 1.45 & 6.35 \\
\hline 7 & 625 & 35000 & 0.1125 & 0.48 & 1.80 & 8.63 \\
\hline 8 & 425 & 35000 & 0.0150 & 0.40 & 1.10 & 2.80 \\
\hline
\end{tabular}
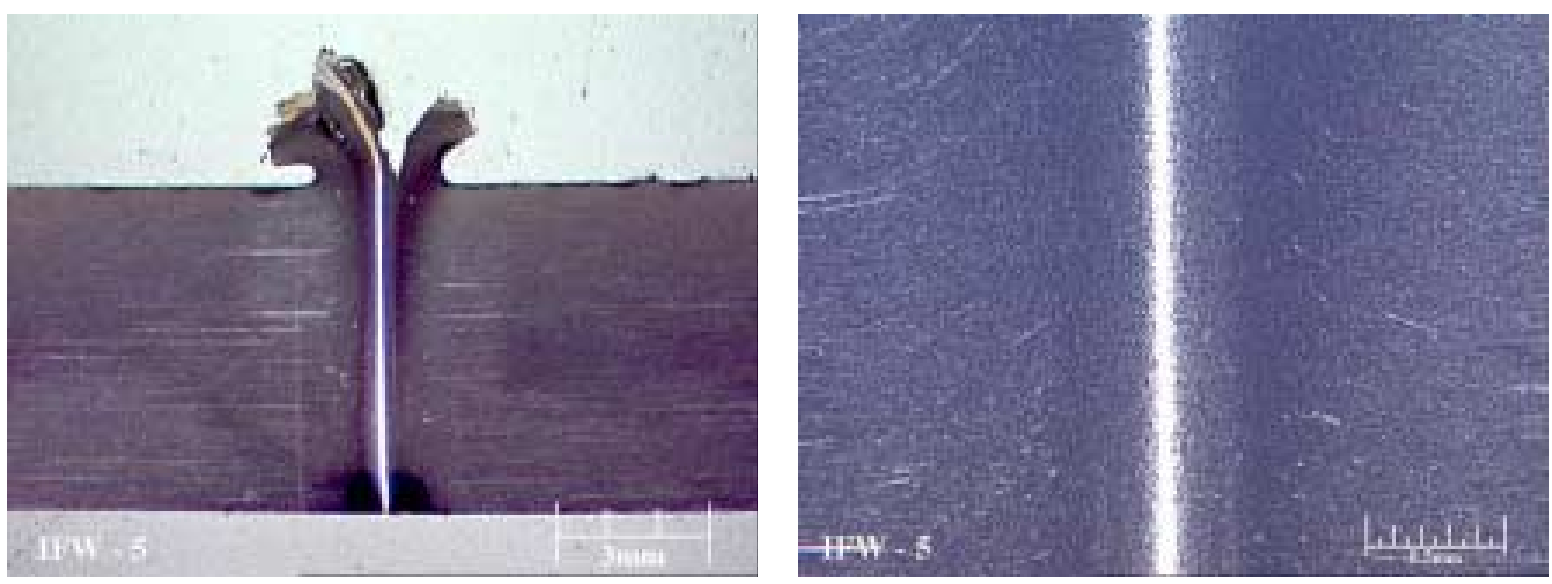

Figure 6. Photomicrographs of inertia weld trial \#5.
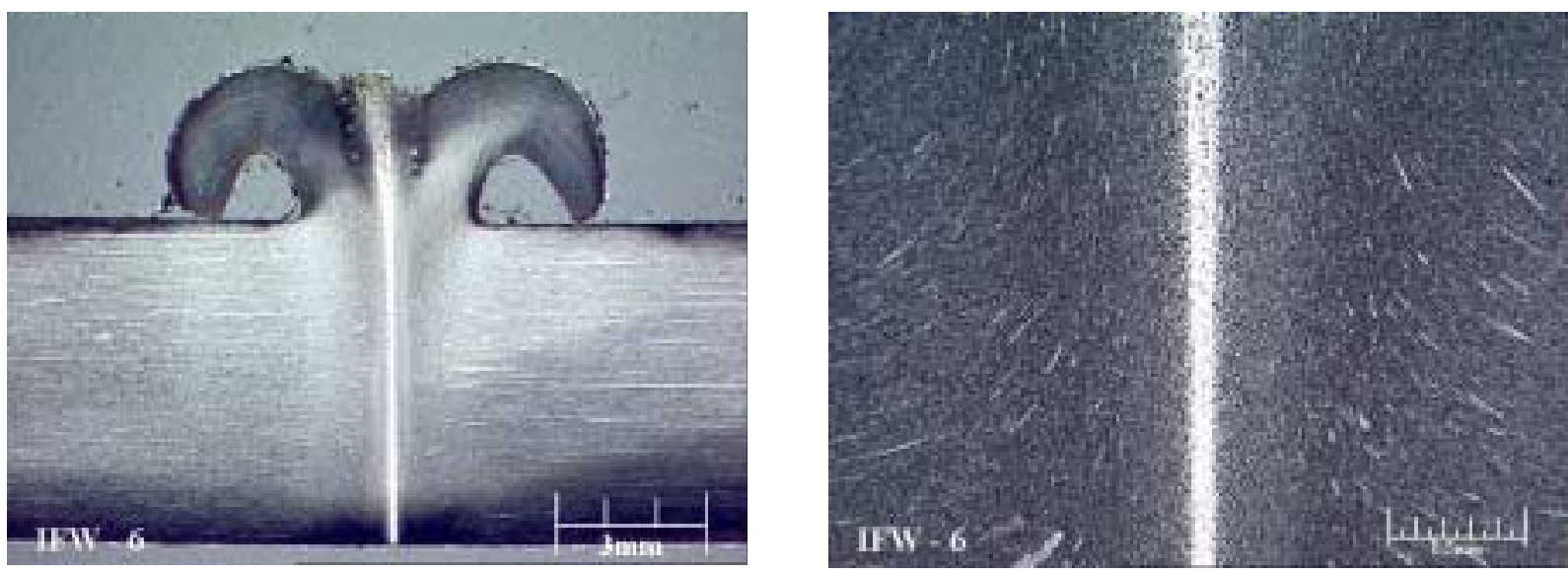

Figure 7. Photomicrographs of inertia weld trial \#6. 

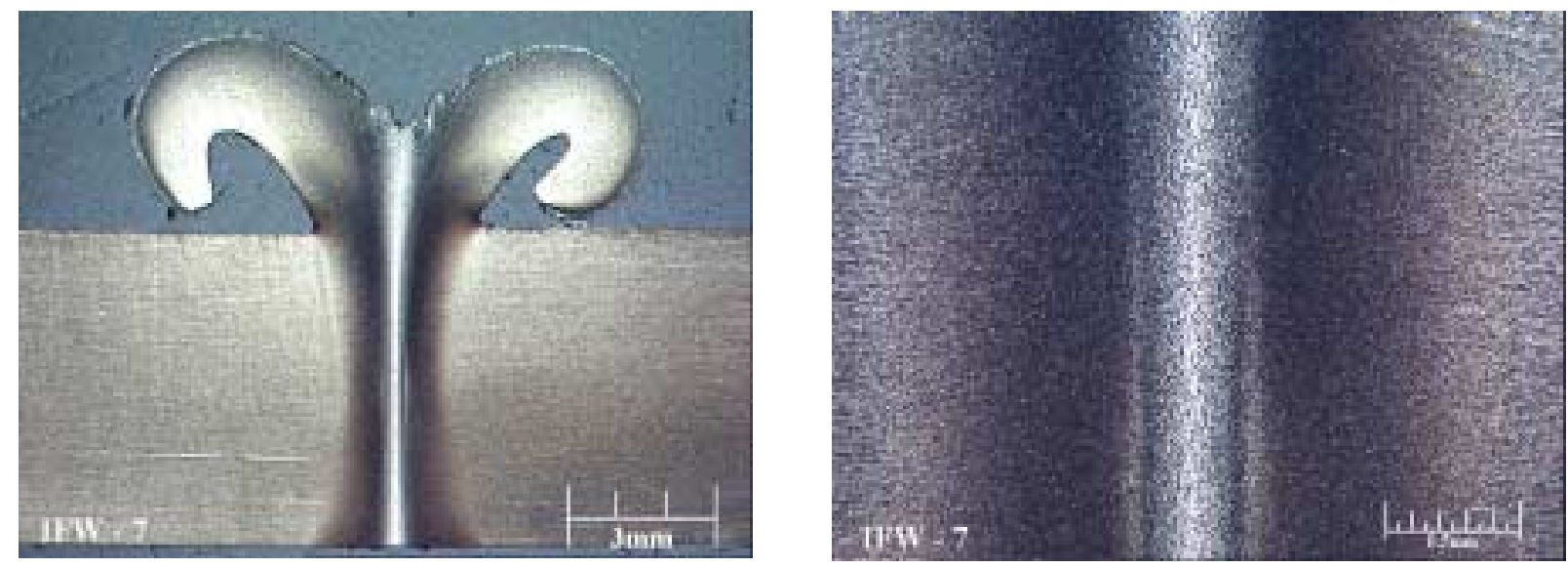

Figure 8. Photomicrographs of inertia weld trial \#7.
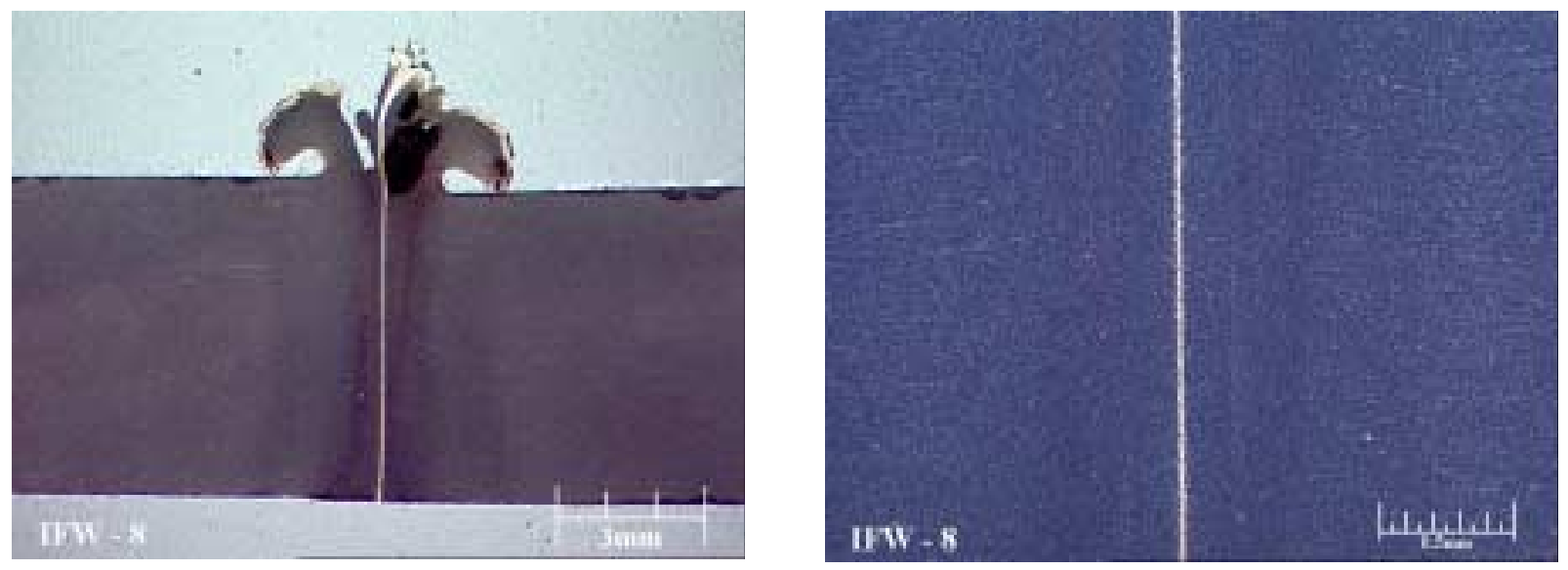

Figure 9. Photomicrographs of inertia weld trial \#8.

Transient Liquid Phase Bonding: Work is continuing on determining the most appropriate hot pressing parameters for joining the MA956 alloy. Results continue to be encouraging and based on the partially-completed parametric study, there may be little benefit to boriding one or both of the mating MA956 surfaces prior to bonding. Even with the low levels of boron added using the protocols developed earlier in the program, nearly all of the borided joints continue to exhibit residual borides at the joint interface, which may inhibit grain growth across the interface after bonding. Workpieces bonded with out boron, however, show a relatively clean interface and evidence of grain growth across this interface. Figure 10, for example, shows a ring of recrystallized MA956 tube bonded to a ring unrecrystallized MA956 tube ( 2.5 inch OD x 0.25 inch wall). The two pieces were bonded by hot pressing at $1200^{\circ} \mathrm{C}$ for 2 hours, followed by 4 hours at $1340^{\circ} \mathrm{C}$. Note that there is very little difference in the microstructure between the two pieces or between the joint and the surrounding matrix. Perhaps even more importantly, a number of grains clearly appear to have grown across the interface during bonding. Such a microstructure is likely to exhibit good elevated temperature tensile performance. 


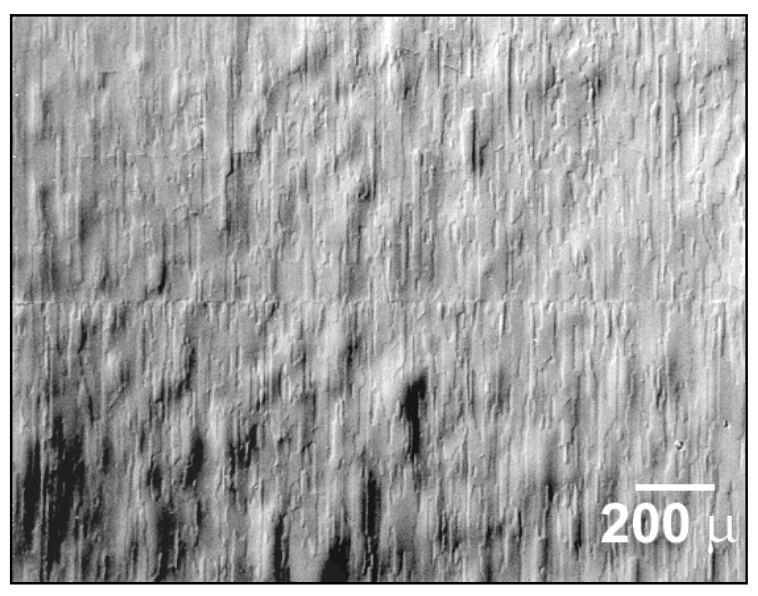

(a)

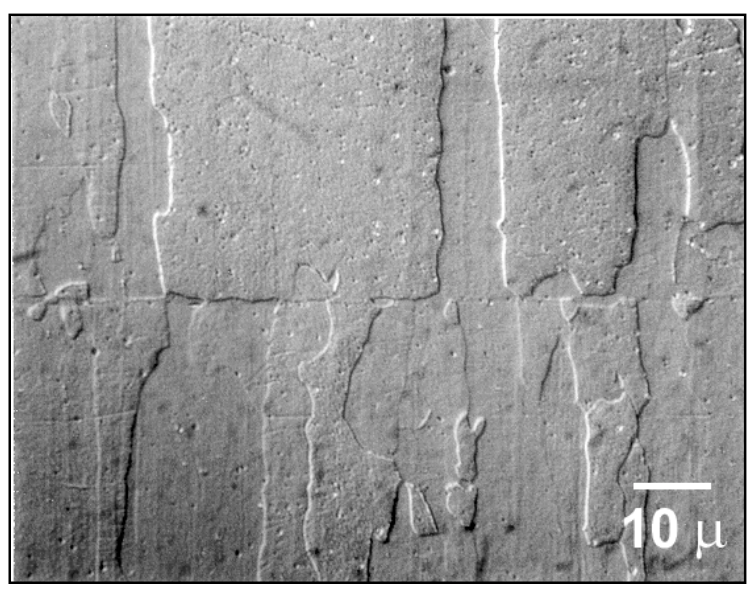

(b)

Figure 10. (a) Micrograph of bond line microstructure produced by hot pressing recrystallized and unrecrystallized MA956 tubing. (b) Higher magnification of microstructure shown in (a).

All of the tubular bonding work to date has been done using the two-piece, butt-joint coupons mentioned above. As indicated at the annual review meeting, however, the Institute believes that joints in these MA956 tubes will ultimately need to be made by joining two recrystallized tubes using an intermediate tapered ring of unrecrystallized material. Samples for initial evaluation of this three-body joint geometry have now been machined and will be bonded during the $7^{\text {th }}$ quarter. Ambient-temperature tensile tests on bonded MA956/MA956 joints are also scheduled to be performed during this quarter, as is initial fabrication of MA956/ Inconel ${ }^{\circledR}$ Alloy 601 joints.

Explosive Welding: During the $6^{\text {th }}$ quarter no additional explosion welds were made.

Magnetic Impulse Welding: The new 90 kJ system was installed in February. In preparation for weld trials, process-modeling activities occurred for design of tooling (coil \& concentrator) in welding the material couples under investigation. The tooling design was completed and the coil and concentrator fabricated by an outside vendor. However, a system "checkout" revealed an inefficient delivery of energy to the workpiece and thus the coil had to be modified. The new or modified coil is scheduled to be available by mid-April, after which validation trials will begin.

In parallel to the equipment validation tasks, tooling/fixturing as well as joint preparation activities continued. MA956 tube material was prepared for welding by producing a lap joint configuration. The tubes were prepared by machining the ID of one tube and the OD of the mating tube so that the 2 tubes will fit together for welding with appropriate standoff distance for magnetic impulse welding. A sketch of the tube joint geometry is shown below in Figure 11. Initial weld trials are to be performed with $1 / 4 \mathrm{t}$ wall thickness (joint thickness 1/2t). A conservative approach is being used initially with this wall thickness to validate the process. Once successful, trials will be carried out with 

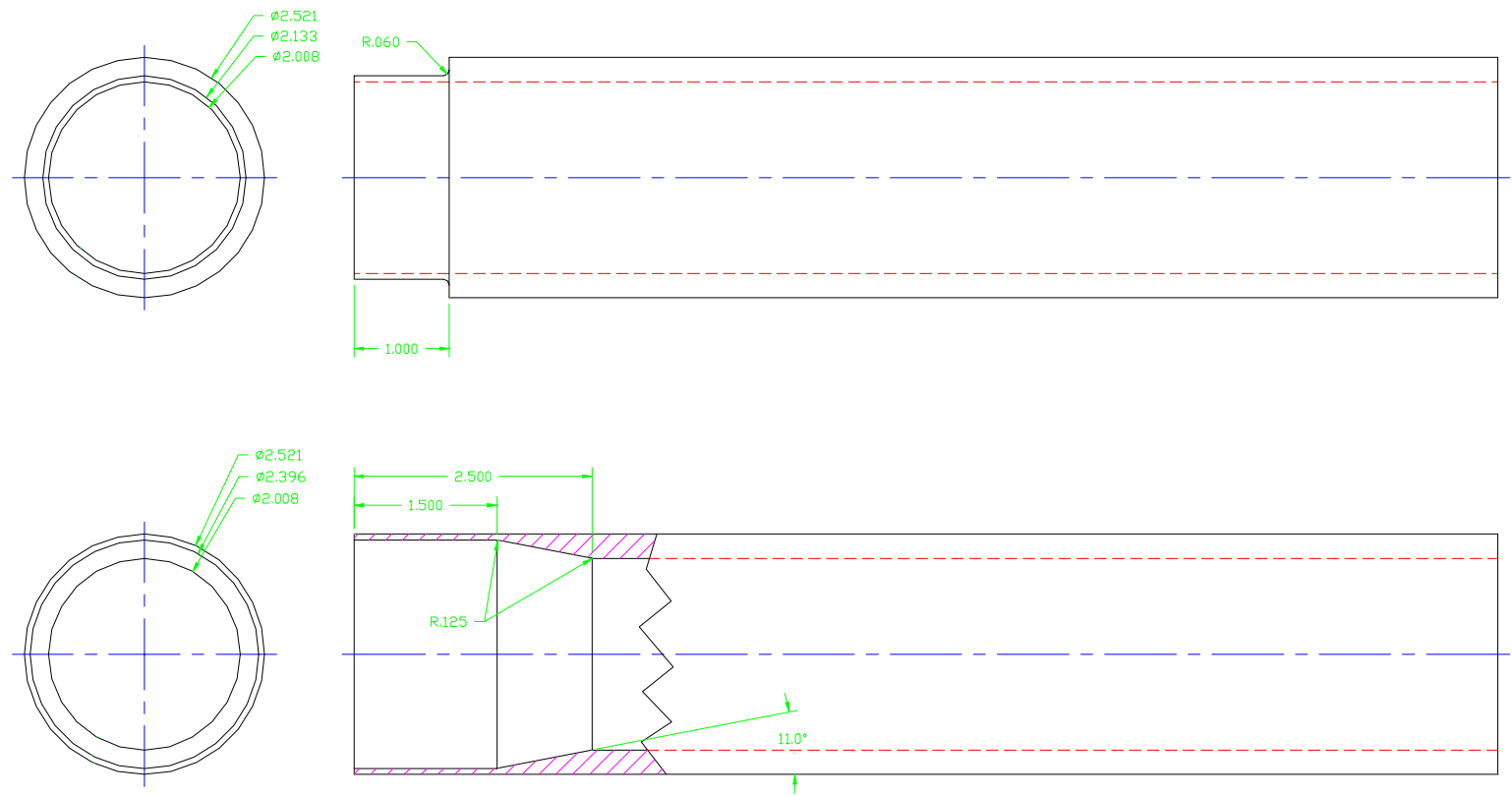

Figure 11. Sketch of lap joint configuration for Magnetic Impulse Welding

increased wall thickness. For initial weld trials with the MA956/IN601 couple, the IN601 tube will be placed outside of the mating MA956 tube. Also, the fixturing and tooling required for welding the tubes has been designed and fabricated. Photos in Figure 12 show equipment setup for welding the MA956 tubes.

\section{Task 4: Bending of MA956 Tubes}

Due to scheduling conflicts in the fabrication shop at FWDC, the tube bending tests were not performed during the $6^{\text {th }}$ quarter.

\section{Task 5: High Temperature Corrosion Limits of MA956}

Laboratory Testing for Working Fluid Side: Lifetime exposure tests at 1250, 1200, and $1100^{\circ} \mathrm{C}$ in air are continuing for the MA956 and MA956HT alloys; there have been no recent failures. Modifications to the lifing model have involved the replacement of the specimen thickness term by a 'shape factor' (volume/surface area). The lifetime data generated on MA956HT in an ORNL in-house program used disc-shaped specimens, whereas the MA956 specimens are parallelepipeds, so that there existed the possibility that the comparison of oxidation behavior was influenced by specimen shape. The range of V/A values of the specimens used so far is 0.03-0.07 cm (discs) and 0.02-0.08 cm (parallelepipeds). Preliminary calculations using the revised model indicate a reasonable fit to the experimental data at $1300^{\circ} \mathrm{C}$, without the use of any 'adjusting' parameters, i.e., assuming strictly parabolic $(n=0.5)$ and linear $(n=1)$ segments to the kinetic curves. Curiously, however, the model now underpredicts the lifetime, especially for the MA956 alloy at $1250^{\circ} \mathrm{C}$. 


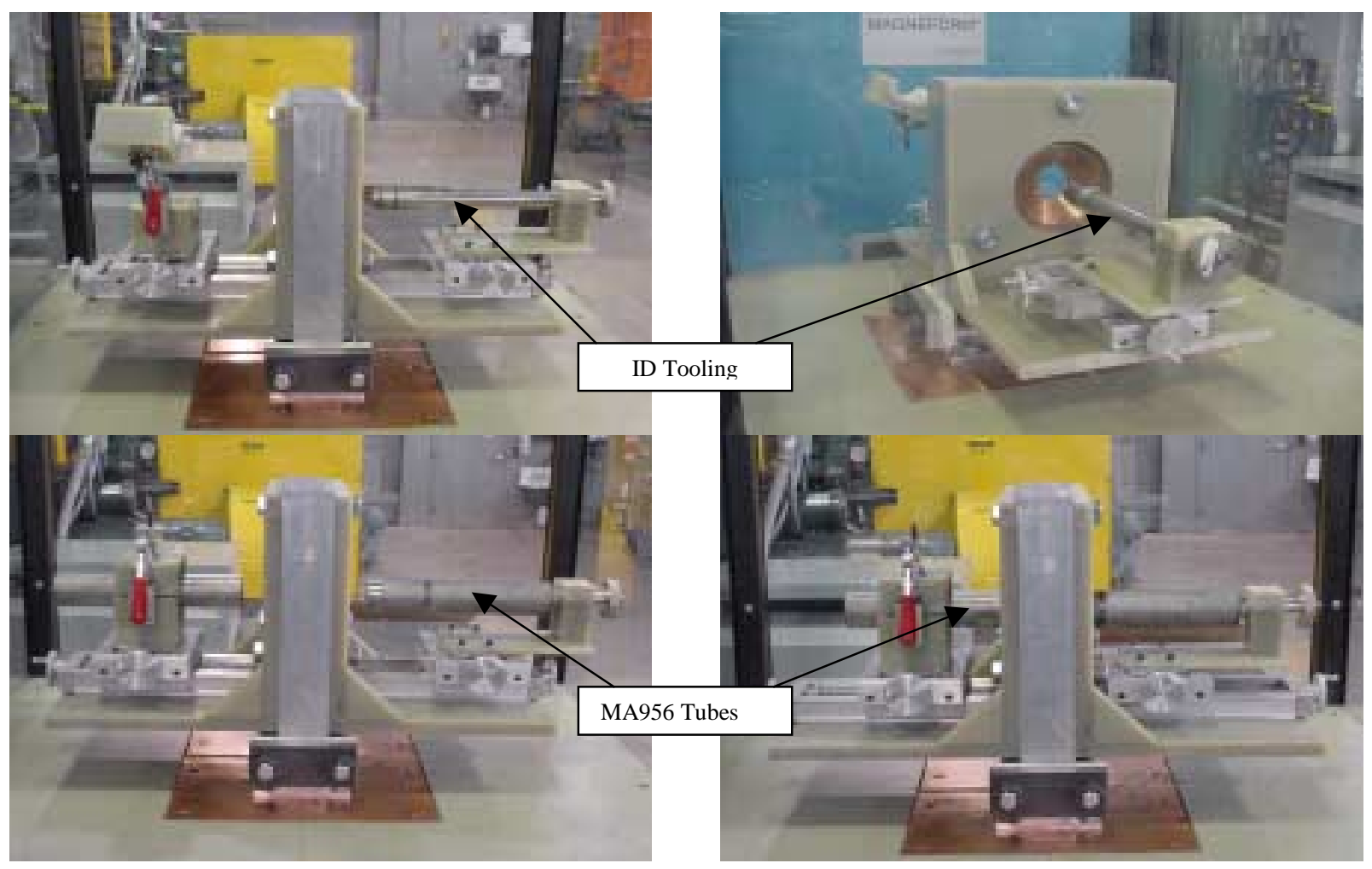

Figure 12. Tooling/fixture set-up for magnetic impulse welding of tube test specimens

Laboratory Testing for Fireside Environment: The laboratory testing using two different flue gases and three different deposits at $2000^{\circ} \mathrm{F}$ continues.

Field Exposure Testing: Nothing new to report.

\section{CONCLUSIONS}

No technical conclusions are available at this time, however the TEM results on samples that have undergone creep is providing valuable information on the mechanical behavior of these alloys. Also, results from the friction and TLP joining studies continue to show promise in this area. Work will continue under Tasks 2, 3, 4, and 5. 